\title{
PENJADWALAN MESIN SCREW PRESS STASIUN KEMPA PADA PRODUKSI CPO (CRUDE PALM OIL) DAN KERNEL DENGAN MENGGUNAKAN METODE INDIKATOR
}

\author{
Heri Wibowo \\ Program Studi Teknik Industri Universitas Malahayati \\ Jl. Pramuka No 27 Kemiling Bandar Lampung 35153 Indonesia \\ Email : heriwibowo_ti@yahoo.co.id
}

\begin{abstract}
Complex problems often encountered in the company, especially the production. The company should be able to increase production capability by increasing the utility of existing resources and accuracy in the completion of production to match the deadlines set by scheduling planned well. As a company produces CPO and kernel continuously so the scheduling screw press machine should be well planned so that production can be completed on time, damage to the engine and overtime can be avoided. This study aims to analyze the utilization schedule and screw press machine at the station felt that optimal production can be achieved and determine the cause of the delay production time resulting in overtime. The method used is the method of indicators that can be applied to the machine which is parallel with different capacities. This method minimizes the turnaround time by prioritizing machine with a large capacity while maintaining the efficiency of the engine and the completion time has been determined. Proposed scheduling using indicators generate optimal schedule, 13840 hours of work available only used 12373.5 hours with five machine screw press, the clock difference is 1408.5 hours of work hours are unemployed and 58 hours of treatment machine screw press, and produce five utilities screw press machine on average up to $89.40 \%$ and utilities average every month five screw press machine is $89.46 \%$. The delay time of CPO production process and the kernel has been caused by damage to machine screw press which occur during the production process takes place so that if the production capacity is reduced and overtime hours cannot be avoided. Screw press machine maintenance can be done by the engine maintenance schedule time without having to wait for the machine was broken beforehand and this can reduce the cost of production.
\end{abstract}

Keywords : Indicator Method, Scheduling Engine

\section{PENDAHULUAN}

Dalam suatu perusahaan banyak ditemukan permasalahan yang kompleks, terutama pada bagian produksi. Masalah penjadwalan sering muncul apabila terdapat sekumpulan tugas yang akan dikerjakan, bagaimana mengalokasikan tugas-tugas tersebut pada mesin, bagaimana urutan kerja, kapan memulai dan menyelesaikan suatu produksi, sehingga diperolah suatu proses produksi yang terjadwal. Penjadwalan yang kurang direncanakan dengan baik dapat mengakibatkan waktu penyelesaian sering terlambat, kerja lembur dan pada saat yang bersamaan sumber daya tidak termanfaatkan dengan baik. Penjadwalan harus direncanakan dengan baik agar proses produksi dapat diselesaikan tepat pada waktunya, kerusakan pada mesin dapat dihindari sehingga tidak perlu dilakukan kerja lembur. Salah satu cara yang dapat dilakukan adalah dengan menjadwalkan mesin produksi yang tepat sesuai dengan kapasitasnya, perhitungan lama waktu produksi, waktu perawatan mesin serta perencanaan waktu mulai dan selesainya produksi dengan menyesuaikan jam kerja mesin yang tersedia. Penjadwalan yang dilakukan oleh perusahaan selama ini masih kurang efektif karena berdasarkan pengalaman dimasa lalu, belum memakai metode penjadwalan tertentu yang sesuai dengan situasi dan kondisi mesin-mesin produksi. Terkadang masih terdapat jam kerja menganggur namun dilain waktu harus dilakukan kerja lembur untuk mengejar keterlambatan produksi dikarenakan adanya mesin yang mengalami kerusakan. 


\section{KAJIAN PUSTAKA}

Penjadwalan secara umum dapat diartikan sebagai pengalokasian sumber daya yang terbatas untuk mengerjakan sejumlah pekerjaan. Menurut Rosnani Ginting (2009), penjadwalan adalah pengurutan pembuatan/pengerjaan produk secara menyeluruh yang dikerjakan pada beberapa buah mesin. Penjadwalan juga merupakan alat ukur yang baik bagi perencanaan agregat. Penjadwalan (schedulling) menurut Beker dalam buku Sofyan Assauri (1997) didefinisikan sebagai pengalokasian sekumpulan sumber untuk menyelesaikan sekumpulan pekerjaan selama periode tertentu dan pengurutan (sequencing) adalah penentuan urutan kedatangan dari bermacam-macam tugas pekerjaan yang harus diselesaikan dalam jangka waktu tertentu. Sedangkan menurut Richard W. Conway dalam buku Sofyan Assauri (1997) mendefinisikan penjadwalan (schedulling) sebagai proses pengurutan secara menyeluruh pada beberapa mesin dan pengurutan (sequencing) didefinisikan sebagai proses pembuatan produk pada satu mesin jangka waktu tertentu. Secara umum penjadwalan dapat didefinisikan sebagai suatu pengambilan keputusan tentang penyesuaian aktifitas dan sumber daya dalam rangka menyelesaikan sekumpulan pekerjaan agar tepat pada waktunya dan mempunyai kualitas seperti yang diinginkan. Model penjadwalan dapat dibedakan menjadi 4 jenis keadaan (Ginting, 2009), yaitu:

1. Berdasarkan mesin yang digunakan dalam proses

a. Proses pada mesin tunggal

b. Proses pada mesin jamak

2. Berdasarkan pola aliran proses

a. Aliran flow shop, pada pola aliran flow shop dijumpai pola aliran proses dari urutan tertentu yang sama. Flow shop terbagi menjadi pure flow shop dan general flow shop. Pada pure flow shop berbagai pekerjaan akan mengalir pada lini produksi yang sama dan tidak dimungkinkan adanya variasi. Sedangkan pada general flow shop dimungkinkan adanya variasi antara pekerjaan atau pekerjaan yang datang tidak harus dikerjakan disemua mesin. (Buffa, 1996)

b. Aliran job shop, pada pola aliran job shop setiap pekerjaan memiliki pola aliran kerja yang berbeda. Aliran proses yang tidak searah ini mengakibatkan pekerjaan yang di kerjakan suatu mesin dapat berupa pekerjaan baru atau pekerjaan yang sedang dikerjakan (work in process) atau pekerjaan yang menjadi produk jadi telah diproses di mesin tersebut. (Buffa, 1996)

3. Berdasarkan pola kedatangan job

a. Kedatangan statis, pada pola ini pekerjaan datang bersamaan pada waktu nol dan siap dikerjakan atau kedatangan pekerjaan bisa tidak bersamaan tetapi saat kedatangan telah diketahui sejak waktu nol.

b. Kedatangan dinamis, mempunyai sifat kedatangan pekerjaan tidak menentu.

4. Berdasarkan sifat informasi yang diterima

a. Deterministik, memiliki kepastian informasi tentang parameter dalam model, misalnya informasi tentang waktu kedatangan pekerjaan, jumlah mesin, kapasitas mesin dan waktu proses.

b. Stokastik, mengandung unsur ketidakpastian.

Metode indikator merupakan suatu alat dalam metode penugasan yang bertujuan mengatasi masalah penjadwalan penugasan pekerjaan dengan membandingkan nilai keseluruhan dengan nilai terkecil untuk menghasilkan penjadwalan yang optimal. Metode indikator ini digunakan untuk menentukan penugasan terhadap satu mesin dari beberapa mesin yang tersedia, namun dengan kapasitas dan waktu operasi yang berbeda. Metode penjadwalan ini dapat diterapkan pada perusahaan yang mesin produksinya bersifat paralel dengan kapasitas yang berbeda serta dengan batas waktu penyelesaian tertentu untuk melakukan suatu proses pekerjaan. Penjadwalan $m$ mesin paralel dengan kapasitas berbeda dengan metode indikator ini digunakan untuk menyusun bagaimana mengalokasikan orderorder yang diterima pada mesin-mesin produksi dengan kapasitas yang berbeda sehingga dapat menghasilkan suatu produksi yang optimal. Metode indikator dalam menentukan 
penjadwalan penugasan pekerjaan, tidak menunjukan pekerjaan mana yang harus dikerjakan terlebih dahulu dan mana yang akan dikerjakan kemudian, tetapi hanya mengetahui mesin mana yang akan mengerjakan pekerjaan, sehingga penugasan yang dibuat menjadi optimal ditinjau dari waktu yang tersedia, yaitu penentuan penugasan pekerjaan (job assignment) untuk tujuan meminimumkan waktu menganggur (idle time) dan meminimumkan waktu proses produksi (makespan) yaitu dengan memprioritaskan suatu order pada mesin dengan kapasitas yang terbesar. Adapun data-data yang diperlukan dalam penjadwalan dengan metode indikator ini adalah data permintaan, data jumlah mesin screw press, data kapasitas masing-masing mesin screw press, jam kerja yang tersedia dan jadwal perawatan mesin. Langkah-langkah pengerjaan menggunakan metode indikator dalam penjadwalan penugasan pekerjaan adalah sebagai berikut :

1. Penentuan kapasitas mesin-mesin produksi

Kapasitas mesin merupakan kemampuan mesin untuk dapat memproduksi atau memproses suatu produk, kapasitas dapat dinyatakan unit/jam, jumlah/jam, ton/jam, $\mathrm{kg} / \mathrm{jam}$ dan lain-lain.

2. Menghitung waktu proses produksi yang diperlukan

Waktu proses yang diperlukan adalah jumlah waktu yang diperlukan untuk memproses dan memproduksi suatu order, rumus penghitungannya dapat dinyatakan sebagai berikut: (Prasetya, 2009)

Waktu proses jam = volume / kapasitas

3. Menghitung nilai indikator

Nilai indikator merupakan nilai yang didapat dari pembagian jam operasi mesin dengan jam operasi mesin terkecil, nilai indikator dapat diperoleh dengan rumus: (Nizomtrs, 2013)

Nilai indikator $=$ waktu proses mesin $/$ waktu proses terkecil

4. Penugasan mesin dan penjadwalan produksi

Mesin yang memiliki nilai indikator terkecil adalah mesin yang akan digunakan untuk memproduksi permintaan dengan syarat bahwa menyesuaikan jadwal perawatan mesin dan waktu yang tersedia dapat memenuhi waktu yang dibutuhkan mesin untuk memproses dan menyelesaikan permintaan, namun jika waktunya tidak memenuhi maka permintaan dapat dialokasikan pada mesin yang nilai indikatornya lebih besar dari mesin tersebut dan begitu selanjutnya.

Kapasitas adalah kemampuan pembatas dari unit produksi untuk diproduksi dalam waktu tertentu dan biasanya dinyatakan dalam bentuk keluaran (output) per satuan waktu. Untuk berbagai kegiatan dapat disesuaikan dengan tingkat penjualan yang berfluktuasi dalam jadwal produksi induk. Kapasitas dan jadwal induk sangat penting karena penjadwalan produksi mencerminkan apa yang akan diproduksi, kemampuan untuk memenuhi rencana tersebut tergantung pada kapasitas mesin. Utilitas mesin adalah suatu ukuran bagaimana memanfaatkan secara intensif sumber daya yang ada. Utilitas dapat dihitung dengan membagi antara waktu proses dengan waktu yang tersedia. Secara teori ukuran maksimum utilitas adalah 1 atau 100\% namun untuk mencapai ukuran maksimum sangat sulit karena mesin pasti mengalami down time, dapat disebabkan mesin break down, absennya operator atau tidak adanya pekerjaan. Adapun rumus dari utilitas mesin atau pemakaian mesin tersebut adalah sebagai berikut (Ginting, 2009) :

Utilitas Mesin = jam kerja / jam tersedia

Rata-rata pemakaian mesin dapat dihitung dengan rumus :

Rata-rata Utilitas Mesin = total utilitas / jumlah mesin 


\section{METODOLOGI PENELITIAN}

Tahap awal penelitian adalah mengumpulkan data jumlah mesin Screw Press, kapasitas mesin Screw Press, permintaan minyak sawait, jadwal perawatan berdasarkan jam kerja mesin dan kalender kerja bulan Juli-Desember tahun 2014. Kemudian dilakukan pengolahan data melalui perhitungan kapasitas mesin, data order produksi, jam kerja yang tersedia, waktu proses produksi, nilai indikator dan penjadwalan mesin

\section{HASIL DAN PEMBAHASAN}

Tabel 1. Jenis Dan Kapasitas Mesin Screw Press

\begin{tabular}{|c|l|c|}
\hline No. & \multicolumn{1}{|c|}{ Jenis/Merk Mesin } & Kapasitas (ton/jam) \\
\hline 1 & Usine de Wecker 1 & 15 \\
\hline 2 & Usine de Wecker 2 & 15 \\
\hline 3 & Stork 1 & 10 \\
\hline 4 & Stork 2 & 10 \\
\hline 5 & Speichim & 10 \\
\hline
\end{tabular}

Perhitungan waktu proses produksi diperlukan untuk menyelesaikan produksi pada tiap-tiap mesin produksi. Data yang diperlukan dalam penghitungan ini adalah kapasitas mesin produksi dan data permintaan minyak bulan Juli - Desember tahun 2014. Contoh perhitungan waktu proses produksi pada permintaan minyak tanggal 01 Juli 2014 sebanyak 5715 ton TBS :

$$
\begin{aligned}
\text { Waktu proses produk }(\mathrm{jam}) & =5715 \mathrm{ton} / 60 \mathrm{ton} \\
& =95.25 \mathrm{jam} \\
\text { Waktu proses produk }(\text { hari }) & =95.25 \mathrm{jam} / 16 \mathrm{jam} \\
& =5.95 \mathrm{hari} \approx 6 \mathrm{hari}
\end{aligned}
$$

\begin{tabular}{|c|c|c|c|c|}
\hline \multicolumn{2}{|c|}{ Bulan dan Tanggal } & TBS (Ton) & Waktu Proses (Jam) & Waktu Proses \\
\hline \multirow{4}{*}{ Juli } & 01 & 5715 & 95.25 & 6 \\
\hline & 08 & 3810 & 63.5 & 4 \\
\hline & 13 & 5715 & 95.25 & 6 \\
\hline & 21 & 7620 & 127 & 8 \\
\hline \multirow{5}{*}{ Agustus } & 03 & 7620 & 127 & 8 \\
\hline & 08 & 5715 & 95.25 & 6 \\
\hline & 18 & 3810 & 63.5 & 4 \\
\hline & 24 & 3810 & 63.5 & 4 \\
\hline & 31 & 5715 & 95.25 & 6 \\
\hline \multirow{7}{*}{ September } & 05 & 5715 & 95.25 & 6 \\
\hline & 08 & 3810 & 63.5 & 4 \\
\hline & 09 & 1905 & 31.75 & 2 \\
\hline & 15 & 5715 & 95.25 & 6 \\
\hline & 17 & 3810 & 63.5 & 4 \\
\hline & 21 & 3810 & 63.5 & 4 \\
\hline & 26 & 1905 & 31.75 & 2 \\
\hline \multirow{5}{*}{ Oktober } & 01 & 7620 & 127 & 8 \\
\hline & 10 & 3810 & 63.5 & 4 \\
\hline & 15 & 5715 & 95.25 & 6 \\
\hline & 27 & 5715 & 95.25 & 6 \\
\hline & 31 & 3810 & 63.5 & 4 \\
\hline
\end{tabular}

Penghitungan waktu proses produksi selengkapnya dapat dilihat pada Tabel 2.

Tabel 2. Perhitungan Waktu Proses Produksi Bulan Juli - Desember 2014 


\begin{tabular}{|c|c|c|c|c|}
\hline \multirow{4}{*}{ November } & 05 & 3810 & 63.5 & 4 \\
\cline { 2 - 5 } & 14 & 1905 & 31.75 & 2 \\
\cline { 2 - 5 } & 19 & 5715 & 95.25 & 6 \\
\cline { 2 - 5 } & 24 & 3810 & 63.5 & 4 \\
\cline { 2 - 5 } & 29 & 3810 & 63.5 & 6 \\
\hline \multirow{4}{*}{ Desember } & 04 & 5715 & 95.25 & 6 \\
\cline { 2 - 5 } & 09 & 5715 & 95.25 & 4 \\
\cline { 2 - 5 } & 15 & 3810 & 63.5 & 6 \\
\cline { 2 - 5 } & 20 & 7620 & 127 & 157 \\
\hline \multicolumn{2}{|c|}{ J u m la h } & 5715 & 95.25 & \\
\hline
\end{tabular}

Contoh perhitungan waktu proses produksi mesin screw press pada permintaan 7620 ton TBS :

Waktu proses produksi mesin UW $1(\mathrm{jam})=7620$ ton $/ 15=508 \mathrm{jam}$

Penghitungan waktu proses produksi selengkapnya dapat dilihat pada tabel 3.

Tabel 3. Waktu Proses Produksi Mesin Screw Press

\begin{tabular}{|c|c|c|c|c|c|c|}
\hline \multirow{2}{*}{ No. } & \multirow{2}{*}{ TBS (Ton) } & \multicolumn{5}{|c|}{ Waktu Proses Mesin (Jam) } \\
\cline { 3 - 7 } & & UW 1 & UW 2 & ST 1 & ST 2 & SP \\
\hline 1 & 7620 & 508 & 508 & 762 & 762 & 762 \\
\hline 2 & 5715 & 381 & 381 & 571.5 & 571.5 & 571.5 \\
\hline 3 & 3810 & 254 & 254 & 381 & 381 & 381 \\
\hline 4 & 1905 & 127 & 127 & 190.5 & 190.5 & 190.5 \\
\hline
\end{tabular}

Pada tabel perhitungan proses produksi tiap mesin screw press terlihat bahwa waktu pemrosesan terkecil tiap permintaan adalah pada mesin UW 1 (Usine de Wecker 1) dan mesin UW 2 (Usine de Wecker 2) karena kedua mesin tersebut memiliki kapasitas olah TBS yang paling besar dari tiga mesin screw press lainnya. Contoh perhitungan nilai indikator pada mesin UW 1 dalam memproses 7620 ton TBS :

Nilai indikator mesin UW $1=508 / 508$

$$
=1
$$

Waktu proses mesin yang dibandingkan adalah 508 jam (UW 1), 508 jam (UW 2), 762 jam (ST 1), 762 jam (ST 2), 762 jam (SP). Dari kelima waktu proses mesin tersebut diperoleh waktu proses mesin terkecil yaitu 508 jam. Sehingga untuk menghitung nilai indikator masing-masing mesin dilakukan dengan membandingkan waktu proses kelima mesin dengan 508 jam. Perhitungan nilai indikator pada masing-masing mesin screw press dari permintaan minyak selengkapnya pada tabel 4

Tabel 4. Perhitungan Nilai Indikator Mesin Screw Press

\begin{tabular}{|c|c|c|c|c|c|c|c|}
\hline \multirow{2}{*}{$\begin{array}{c}\text { No } \\
\text {. }\end{array}$} & \multirow{2}{*}{ Jenis/Merk Mesin } & \multirow{2}{*}{$\begin{array}{c}\text { Kapasitas } \\
\text { (ton/jam) }\end{array}$} & \multicolumn{4}{|c|}{ Waktu Proses Mesin (Jam) } & \multirow{2}{*}{$\begin{array}{c}\text { Nilai } \\
\text { Indikator }\end{array}$} \\
\hline & & & 7620 & 5715 & 3810 & 1905 & \\
\hline 1 & Usine de Wecker 1 & 15 & 508 & 381 & 254 & 127 & 1 \\
\hline 2 & Usine de Wecker 2 & 15 & 508 & 381 & 254 & 127 & 1 \\
\hline 3 & Stork 1 & 10 & 762 & 571.5 & 381 & 190.5 & 1.5 \\
\hline 4 & Stork 2 & 10 & 762 & 571.5 & 381 & 190.5 & 1.5 \\
\hline 5 & Speichim & 10 & 762 & 571.5 & 381 & 190.5 & 1.5 \\
\hline
\end{tabular}


Tabel 5. Hasil Penjadwalan Mesin Screw Press Stasiun Kempa

\begin{tabular}{|c|c|c|c|c|c|}
\hline \multicolumn{2}{|c|}{$\begin{array}{c}\text { Bulan dan } \\
\text { Tanggal }\end{array}$} & $\begin{array}{l}\text { TBS } \\
\text { (Ton) }\end{array}$ & Waktu Produksi & Tanggal Perawatan & Alokasi Mesin \\
\hline \multirow{4}{*}{ Juli } & 01 & 5715 & 01 Juli - 06 Juli & 01,06 Juli & UW 1, UW 2, ST 1, ST 2, SP \\
\hline & 08 & 3810 & 07 Juli - 10 Juli & 07 Juli & UW 1, UW 2, ST 1, ST 2, SP \\
\hline & 13 & 5715 & 11 Juli -16 Juli & - & UW 1, UW 2, ST 1, ST 2, SP \\
\hline & 21 & 7620 & 17 Juli -24 Juli & $21 \mathrm{Juli}$ & UW 1, UW 2, ST 1, ST 2, SP \\
\hline \multirow{5}{*}{ Agustus } & 03 & 7620 & 25 Juli - 07 Agustus & 06 Agustus & UW 1, UW 2, ST 1, ST 2, SP \\
\hline & 08 & 5715 & 08 Agustus - 11 Agustus & 11 Agustus & UW 1, UW 2, ST 1, ST 2, SP \\
\hline & 18 & 3810 & 12 Agustus - 15 Agustus & 12 Agustus & UW 1, UW 2, ST 1, ST 2, SP \\
\hline & 24 & 3810 & 16 Agustus - 20 Agustus & - & UW 1, UW 2, ST 1, ST 2, SP \\
\hline & 31 & 5715 & 21 Agustus - 26 Agustus & - & UW 1, UW 2, ST 1, ST 2, SP \\
\hline \multirow{7}{*}{ September } & 05 & 5715 & 27 Agustus - 01 September & 28 Agustus & UW 1, UW 2, ST 1, ST 2, SP \\
\hline & 08 & 3810 & 02 September - 05 September & - & UW 1, UW 2, ST 1, ST 2, SP \\
\hline & 09 & 1905 & 06 September - 07 September & 07September & UW 1, UW 2, ST 1, ST 2, SP \\
\hline & 15 & 5715 & 08 September - 14 September & $08,12,13$ September & UW 1, UW 2, ST 1, ST 2, SP \\
\hline & 17 & 3810 & 15 September -17 September & - & UW 1, UW 2, ST 1, ST 2, SP \\
\hline & 21 & 3810 & 18 September -21 September & - & UW 1, UW 2, ST 1, ST 2, SP \\
\hline & 26 & 1905 & 22 September - 23 September & 22 September & UW 1, UW 2, ST 1, ST 2, SP \\
\hline \multirow{5}{*}{ Oktober } & 01 & 7620 & 24 September - 01 Oktober & 27, 28 September & UW 1, UW 2, ST 1, ST 2, SP \\
\hline & 10 & 3810 & 02 Oktober - 06 Oktober & - & UW 1, UW 2, ST 1, ST 2, SP \\
\hline & 15 & 5715 & 07 Oktober - 12 Oktober & 08,10 Oktober & UW 1, UW 2, ST 1, ST 2, SP \\
\hline & 27 & 5715 & 13 Oktober -19 Oktober & 13,14 Oktober & UW 1, UW 2, ST 1, ST 2, SP \\
\hline & 31 & 3810 & 20 Oktober - 22 Oktober & - & UW 1, UW 2, ST 1, ST 2, SP \\
\hline \multirow{5}{*}{ November } & 05 & 3810 & 23 Oktober -27 Oktober & 23 Oktober & UW 1, UW 2, ST 1, ST 2, SP \\
\hline & 14 & 1905 & 28 Oktober -29 Oktober & 29 Oktober & UW 1, UW 2, ST 1, ST 2, SP \\
\hline & 19 & 5715 & 30 Oktober - 04 November & 30 Oktober & UW 1, UW 2, ST 1, ST 2, SP \\
\hline & 24 & 3810 & 05 November - 08 November & 08 November & UW 1, UW 2, ST 1, ST 2, SP \\
\hline & 29 & 3810 & 09 November - 12 November & 11 November & UW 1, UW 2, ST 1, ST 2, SP \\
\hline \multirow{5}{*}{ Desember } & 04 & 5715 & 13 November - 19 November & 13, 14 November & UW 1, UW 2, ST 1, ST 2, SP \\
\hline & 09 & 5715 & 20 November -24 November & 23 November & UW 1, UW 2, ST 1, ST 2, SP \\
\hline & 15 & 3810 & 25 November -29 November & $26,28,29$ November & UW 1, UW 2, ST 1, ST 2, SP \\
\hline & 20 & 7620 & 30 November - 06 Desember & - & UW 1, UW 2, ST 1, ST 2, SP \\
\hline & 28 & 5715 & 07 Desember - 12 Desember & 8, 11 Desember & UW 1, UW 2, ST 1, ST 2, SP \\
\hline
\end{tabular}

Hasil dari penjadwalan mesin screw press, diketahui jam kerja mesin yang diperlukan untuk memproses seluruh permintaan periode Juli-Desember 2014. Jam kerja mesin diperlukan dapat dilihat pada tabel 6 .

Tabel 6. Jam Kerja Mesin Screw Press yang Diperlukan

\begin{tabular}{|c|l|c|c|c|c|c|c|}
\hline \multirow{2}{*}{ No. } & \multirow{2}{*}{ Bulan } & \multicolumn{7}{|c|}{ Waktu (Jam) } & \multirow{2}{*}{$\begin{array}{c}\text { Jumlah } \\
\end{array}$} \\
\cline { 3 - 7 } & & UW 1 & UW 2 & ST 1 & ST 2 & SP & Jam \\
\hline 1 & Juli & 415.7 & 412.5 & 412.5 & 412 & 411.25 & 2063.95 \\
\hline 2 & Agustus & 463.4 & 459.5 & 458.5 & 458.5 & 458.25 & 2298.15 \\
\hline 3 & September & 478.5 & 476.7 & 474 & 475 & 473 & 2377.2 \\
\hline 4 & Oktober & 462.5 & 461 & 459.25 & 459 & 459 & 2300.75 \\
\hline 5 & November & 477 & 476.7 & 476 & 475.5 & 474 & 2379.2 \\
\hline 6 & Desember & 190.5 & 192 & 192 & 1907.5 & 189 & 954.25 \\
\hline \multicolumn{2}{|r}{ Jumlah (Jam) } & 2487.6 & 2478.4 & 2472.25 & 2470.75 & 2464.5 & 12373.5 \\
\hline
\end{tabular}

Utilitas Mesin UW $1=(2487.6 / 2768) \times 100 \%$ $=89.87 \%$ 
Utilitas mesin screw press disajikan pada tabel 7.

Tabel 7. Utilitas Mesin Screw Press

\begin{tabular}{|c|l|c|c|c|}
\hline No. & \multicolumn{1}{|c|}{ Jenis/Merk Mesin } & $\begin{array}{c}\text { Jam Kerja } \\
(\mathrm{jam})\end{array}$ & $\begin{array}{c}\text { Jam Tersedia } \\
(\mathrm{jam})\end{array}$ & $\begin{array}{c}\text { Utilitas Mesin } \\
(\%)\end{array}$ \\
\hline 1 & Usine de Wecker 1 & 2487.6 & 2768 & 89.87 \\
\hline 2 & Usine de Wecker 2 & 2478.4 & 2768 & 89.54 \\
\hline 3 & Stork 1 Utilitas Rata-rata (\%) & 2472.25 & 2768 & 89.32 \\
\hline 4 & Stork 2 & 2470.75 & 2768 & 89.26 \\
\hline 5 & Speichim & 2764.5 & 89.04 \\
\hline \multicolumn{4}{|r|}{} \\
\hline
\end{tabular}

Utilitas lima mesin screw press pada bulan Juli - Desember 2014 disajikan pada tabel 8.

Tabel 8. Utilitas Lima Mesin Screw Press pada Bulan Juli-Desember 2014

\begin{tabular}{|c|l|c|c|c|}
\hline No. & Bulan & $\begin{array}{c}\text { Jam Kerja } \\
\text { (jam) }\end{array}$ & $\begin{array}{c}\text { Jam Tersedia } \\
\text { (jam) }\end{array}$ & $\begin{array}{c}\text { Utilitas Mesin } \\
(\%)\end{array}$ \\
\hline 1 & Juli & 2063.95 & 2080 & 99.23 \\
\hline 2 & Agustus & 2298.15 & 2320 & 99.06 \\
\hline 3 & September & 2377.2 & 2400 & 99.05 \\
\hline 4 & Oktober & 2300.75 & 2320 & 99.17 \\
\hline 5 & November & 2379.2 & 2400 & 99.13 \\
\hline 6 & Desember & 954.25 & 2320 & 41.13 \\
\hline \multicolumn{3}{|r|}{ Utilitas Rata-rata (\%) } \\
\hline
\end{tabular}

Persentase pemanfaatan mesin screw press yang tidak berbeda jauh disebabkan adanya penyesuaian jadwal perawatan mesin untuk mencegah terjadinya kerusakan mesin screw press pada saat proses produksi berlangsung dan penugasan terhadap tiap mesin menggunakan metode indikator berdasarkan prioritas kapasitas mesin terbesar dengan tetap memperhatikan efisiensi sumber daya yang ada. Dari kelima mesin screw press yang ada, Usine de Wecker 1 dan Usine de Wecker 2 menjadi prioritas job dalam penjadwalan karena memiliki kapasitas yang terbesar dibanding tiga mesin screw press yang lain yaitu Stork 1, Stork 2 dan Speichim. Persentase utilitas mesin pada bulan Desember sangat kecil dibandingkan persentase mesin screw press pada bulan-bulan yang lain. Utilitas mesin pada bulan Desember hanya sebesar $41.13 \%$, hal ini disebabkan pada bulan Desember mesinmesin screw press tidak sepenuhnya beroperasi, karena seluruh permintaan CPO untuk periode Juli-Desember 2014 telah terpenuhi pada tanggal 12 Desember 2014. Untuk 16 hari yang tersisa dari tanggal 13 - 31 Desember 2014 pemanfaatan mesin yang menganggur dapat dilakukan dengan memproduksi permintaan CPO untuk periode selanjutnya sehingga permintaan dapat terpenuhi sebelum batas waktu yang ditentukan.

\section{KESIMPULAN}

Berdasarkan hasil dan pembahasan yang telah diuraikan diatas, maka dapat diambil beberapa kesimpulan, yaitu :

1. Penjadwalan mesin screw press sudah optimal, terlihat dari jam kerja mesin-mesin screw press sebanyak 12373.5 jam dan jam kerja yang tersedia dari kelima mesin screw press pada periode Juli-Desember 2014 adalah sebanyak 13840 jam. Selisih dari jam tersebut yaitu 1466.5 jam, 1408.5 jam adalah jam kerja menganggur dan 58 jam melakukan perawatan mesin screw press.

2. Utilitas lima mesin screw press dari hasil pengolahan data selama enam bulan mencapai rata-rata $89.40 \%$, sedangkan utilitas per bulan dari kelima mesin screw press mencapai rata-rata $89.46 \%$. Pemanfaatan rata-rata mesin screw press ini sudah optimal. 
Persentase utilitas yang berbeda terjadi karena pada bulan Desember kelima mesin screw press hanya beroperasi selama 12 hari kerja, sedangkan pada 17 hari kerja yang tersisa kelima mesin screw press menganggur.

3. Keterlambatan waktu proses produksi CPO dan kernel selama ini disebabkan kerusakan mesin screw press yang terjadi saat proses produksi berlangsung sehingga kapasitas olah produksi berkurang dan jam kerja lembur tidak dapat dihindari..

\section{DAFTAR PUSTAKA}

[1] Assuari, Soffyan. 1997. Manajemen Produksi dan Operasi Edisi Keempat. Jakarta : Lembaga Penerbit Fakultas Ekonomi UI Indonesia.

[2] Ariadi, Hari. 2005. Penjadwalan Produksi Kopi Biji Dengan Pekerjaan Empat Prosesor Paralel Menggunakan Pendekatan Metode Indikator di PT. Indocom Citrapersada Tanjung Karang Timur Tahun 2005. Bandar Lampung : Skripsi Program Studi Teknik Industri Universitas Malahayati.

[3] Buffa, Elwood S. Dan Rakesh K. Sarin. 1996. Manajemen Operasi dan Produksi Modern Edisi Kedelapan. Jakarta : Binarupa Aksara.

[4] Ginting, Rosnani. 2009. Penjadwalan Mesin Edisi Pertama. Yogyakarta : Graha Ilmu.

[5] http://nizomtrs.blogspot.com/2013/11/metode-penugasan.html diakses 5 Maret 2014 pukul 22.22 WIB

[7] Naibaho, Ponten M. 1994. Teknologi Pengolahan Kelapa Sawit. Medan : Pusat Penelitian Kelapa Sawit.

[8] Prasetya, Hery dan Fitri Lukiastuti. 2009. Manajemen Operasi Edisi Pertama. Yogyakarta : Media Pressindo.

[9] Render, Barry, dan Jay Heyzer. 2005. Manajemen Operasi Edisi Ketujuh. Jakarta : Salemba Empat.

[10] Render, Barry, dan Jay Heyzer. 2001. Prinsip-Prinsip Manajemen Operasi Edisi Pertama. Jakarta : Salemba Empat.

[11] Schroeder, Roger G. 2000. Manajemen Operasi Jilid 2 Edisi Pertama. Jakarta : Erlangga.

[12] Sumayang, Lalu. 2003. Dasar-Dasar Manajemen Produksi dan Operasi Edisi Ketiga. Jakarta : Salemba Empat. 